\title{
Study of Air Velocity and Temperature Gradient in Lecture Room Through Mixed and Displacement Ventilation Systems to Improve the Thermal Comfort
}

\author{
Bambang Iskandriawan ${ }^{1}$
}

\begin{abstract}
Air ventilation system is considered crucial in the target of maintaining clean and fresh room air at all times. It will improve the thermal comfort and indoor air quality along with the activities of occupant. This investigation explores the influence of fresh air diffuser location to the thermal comfort factor especially in the lecture room. It will contrast two types of ventilation: the mixed and the displacement ventilation. The thermal comfort factor is represented by means of air velocity and temperature. Using Fluent 6.2 as CFD (Computational Fluid Dynamics) simulation program, all the variables will be exploited. The specific boundary type's room model is verified in GAMBIT software generating such a specific lecture room. The finding shows that the displacement ventilation system has benefit in the propensity of controlling the heat and air velocity compare to the mixed ventilation.
\end{abstract}

Keywords $\longrightarrow$ ventilation, mixed, displacement, lecture room, CFD fluent

\section{INTRODUCTION}

Since the energy crisis in the 1970s, the insulation of buildings has been advanced and the ventilation rate has been decreased in order to save energy. However, such a reduction of air may cause an increase in the concentration of indoor pollutants. Draft (thermal control problems) and "sick-building" syndrome (indoor air quality problems) are familiar diseases that are direct results of the poor distribution of airflow. Air ventilation system is operated to take outside the contaminant straight away from the room. The achievement of ventilation design needs the system which is not suffering overloaded with sufficient capacity.

What kinds of performance characteristics are required in analyze of air displacement and mixed ventilation system should be paid close attention to the previous research. The researches which are concern to the displacement ventilation system were done by some researchers. Those activities are implemented due to the lack of success in the conventional air ventilation system.

Some researchers are accomplishing something valuable even though they still need some prolonged work.

Experimental analysis using several air distribution

\footnotetext{
${ }^{1}$ Bambang Iskandriawan is with Department of Industrial Design, FTSP, Institut Teknologi Sepuluh Nopember, Surabaya, 60111, Indonesia. E-mail: bisk@prodes.its.ac.id, iskandriawan10@yahoo.co.uk
}

methods was done by Holmberg et al. [1]. They found that a free convection flow around a person may protect the breathing zone from surrounding contaminants at the head level, but it may also bring contaminants from the source below the breathing zone. King et al. concluded that the accurate application of stratification air conditioning system for the building where the indoor air quality increases could propose some benefit. In case study, more than 1 million kilowatt per annum electrical power operation could be saved, $50.55 \%$ of the operation cost prediction with the conventional system [2]. Ceiling cooler panels are used for high cooling load to improve the ventilation quality [3]. Stratification air temperature and ventilation effectiveness are some significant characteristics of displacement ventilation in accordance with $\mathrm{Hu}$ et al. [4]. Nielsen $[5,6]$ accomplished an experiment with air terminal device which is mounted next to the lower wall. The level of velocity and temperature in the occupation zone could be clarified with single formula and part of them by measurement method.

Air stratification flow with wall mounted supply device is implemented to predict the temperature differences and ventilation effectiveness [7]. The purpose of $\mathrm{Xu}$ et al. is investigating the influence of heat loss through the wall to temperature gradient and contaminant concentration inside the room with displacement ventilation. The influence of air supply temperature and cooling load for temperature gradient and ventilation efficiency [8].

Critic evaluation; performance and design guideline for displacement ventilation system are executed [9], [10]. Lau and Chen [11] examine the performance of displacement ventilation where the air is supplied at floor area with swirl diffuser is compared to perforated diffuser in the high cooling load (about 90 $\mathrm{W} / \mathrm{m}^{2}$ ). Experiment method as the validation is applied for comparison. Some parameters are implemented such as air change hour, the number and location, occupant position, furniture and partition and the exhaust location. Many kind of ventilation system for the buildings are explored fundamentally by Awbi [12]. The author did the experiment and simulation to compare the two extreme kind of ventilation [13]. The purpose of this research is to explore the establishment of unique airflow depend of the position of air supply diffuser is linked to the convective heat transfer knowledge based on computational fluid dynamics method. 


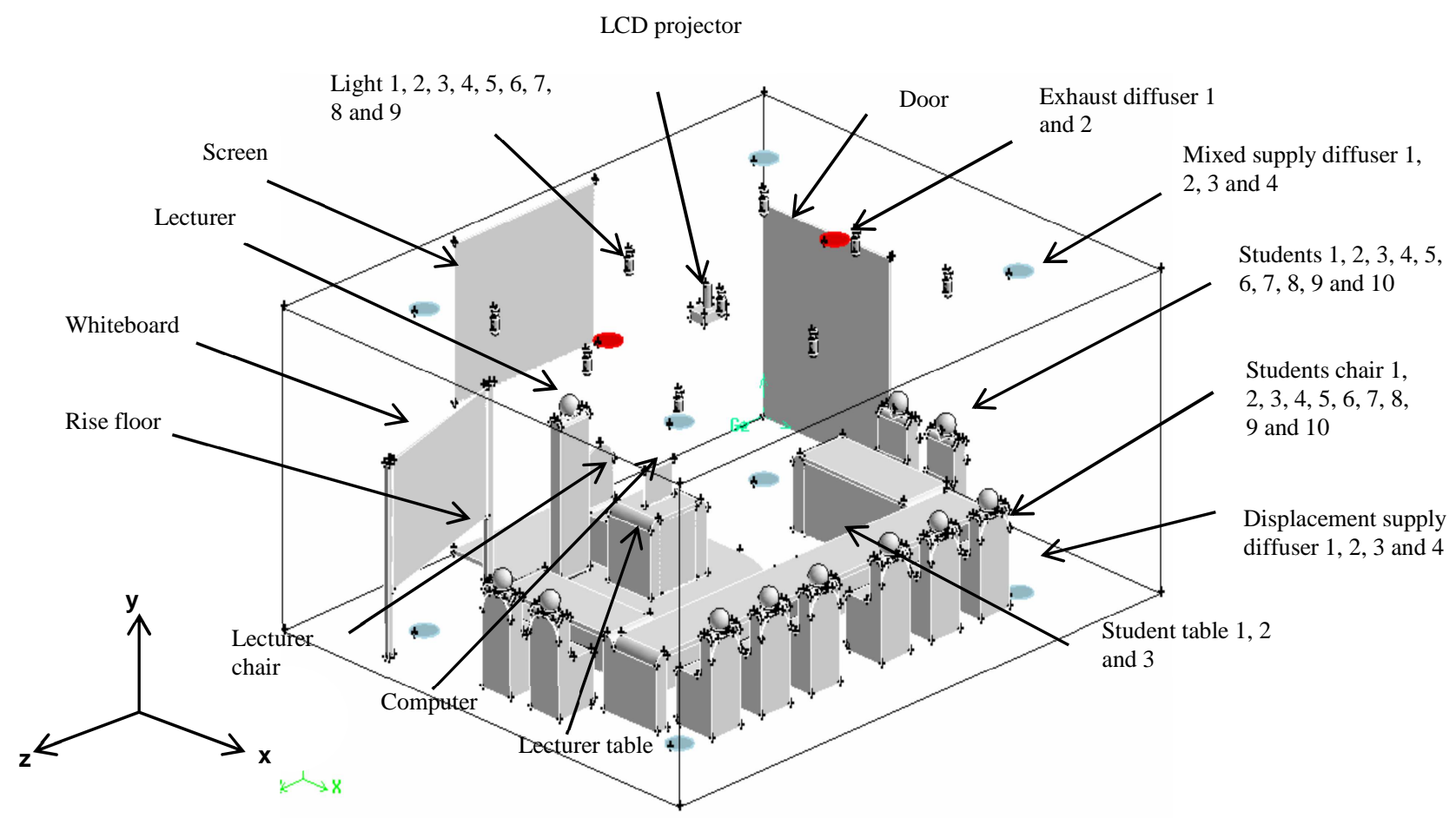

Fig. 1. The model of lecture room is generated in GAMBIT software

The result of this investigation is expected could contribute the long journey to obtain the substantial enhancement to improve the thermal comfort and room air quality especially in the lecture room. This investigation needs to be implemented because our country has specific environment where the outdoor temperature will determine the thermal comfort inside the room.

\section{METHOD}

This research based on the simulation of CFD (Fluent 6.2) with makes use of the location of fresh air diffuser parameter. The CFD simulation is set up with the design of ventilation system and the interior of lecture room derived from the existing principle. The lecture room model was generated in GAMBIT (Geometry and Mesh Building Intelligent Toolkit) software subsequently meshing process was completed. In the Fluent 6.2 is clarified boundary condition system. There were four types of viscous flow: laminar flow also k-epsilon standard, RNG and realized. In this case the laminar flow system is selected by reason of the air velocity inside the lecturer room is low down sufficient.

Based on the architecture regulation standard, the model of lecturer room with the air ventilation system was created as we can see at Fig. 1. There are 15 poles which are used as the position of air velocity and temperature measurement (Fig. 2). Table 1 shows us the air temperature measurement com-parison result of simulation and experiment which is implemented at the previous research [13]. Four va-rieties of ventilation systems which are investigated: mixed centre, mixed side, displacement centre and displacement side.

In this project, the supply diffuser air velocity, $V_{\text {in }}=$ $0.2 \mathrm{~m} / \mathrm{s}$ for mixed and displacement centre where the diffuser diameter $D_{\text {in }}=D_{\text {out }}=300 \mathrm{~mm}$ with the supply air temperature, $T_{i n}=18{ }^{\circ} \mathrm{C}$. The fresh air absorbs heat energy which was generated since the existing of some heat sources: persons, lamp and computer (each has temperature $27^{\circ} \mathrm{C}$ ).

\section{RESULT AND DISCUSSION}

Air flow pattern for two categories of air ventilation system can be seen in Fig. 3 (the mixed ventilation) and Fig. 4 (the displacement ventilation). In the mixed ventilation systems the journey of supply air relatively longer due to the supply air come into the room from the ceiling elevation area down to the lower zone and back to the upper zone continues to the exhaust area. On the other hand, the portion of fresh air moves from the lower zone to the ceiling in the upper zone and out passing through exhaust in the displacement ventilation where the travel is shorter. The turbulence intensity is higher in the mixed ventilation system, where in this case it will influence the aspects of thermal comfort and indoor air quality such as the velocity, temperature and air contamination.

\section{A. Air Velocity}

Plenty of interesting matter in the air velocity analysis based on the position of air supply diffuser and the interior layout.

Lying on the poles 1 and 5 (at the room front corner, Fig. 5) mixed ventilation, the air velocity decreases once the height position decrease. The opposite condition is occurred on the poles 1 and 5 displacement ventilation.

The air velocity increases while the height position decline. The highest velocity is $0.2 \mathrm{~m} / \mathrm{s}$. The lowest velocity (below $0.02 \mathrm{~m} / \mathrm{s}$ ) is occurred in the poles 3 both in the mixed and displacement ventilation due to their position is far-away to the air supply diffuser.

Principally, the velocity curves of mixed ventilation are the mirror of that of the displacement ventilation where the mirror field is the line around the room height $1.5 \mathrm{~m}$ 
for the area poles 1 to 5 .

Velocity gradient for poles 6 to 10 where their position are at the room centre can be seen at Fig. 6. Surprise, the highest velocity is around $0.4 \mathrm{~m} / \mathrm{s}$ that is the area close to the exhaust diffuser (poles 7 and 9). Almost there is no velocity profile difference between mixed and displacement ventilation for poles 7 and 9 . Air velocities are under $0.03 \mathrm{~m} / \mathrm{s}$ for poles 6,8 , and 10 equally in the mixed and displacement ventilation. Velocity profiles at the back of room can be discussed in Fig. 7 .

Similar situation with that at the front of room is happened in this area. The mixed ventilation velocity profile is the mirror of that of the displacement ventilation. The line around the height $1.5 \mathrm{~m}$ is the line of mirror for the poles 11 to 15 .

The role of air velocity is the most important thing in the ventilation design. The discomfort of occupant is depending of the air velocity and temperature in the room [12]. The bigger the air velocity will increase dissatisfy of occupant, where the higher air velocity is needed for the successful ventilation air to bring contaminant away from the room.

\section{B. Air Temperature}

The observation of air temperature is focused at the lower zone height area: $\mathrm{y}=0.25 \mathrm{~m}$ and $\mathrm{y}=0.5 \mathrm{~m}$; occupation zone: $\mathrm{y}=1.0 \mathrm{~m}, \mathrm{y}=1.5 \mathrm{~m}$ and $\mathrm{y}=2.0 \mathrm{~m}$ moreover upper zone: $y=2.5 \mathrm{~m}, \mathrm{y}=2.75 \mathrm{~m}$ and $\mathrm{y}=2.95 \mathrm{~m}$ both for air mixed and displacement ventilation as we can see at Fig. 8 and 9.

The four blue points of the displacement ventilation broader compare to the mixed ventilation for every distance the supply air moves. Commonly, the displacement ventilation will create the cool temperature inside the room contrast to the mixed ventilation used for the three zones. But, if we check accurately there is a small number of areas where the room temperature is higher for the displacement compare to the mixed ventilation. Those are the areas under the tables for the room height $0.25 \mathrm{~m}$ to $0.5 \mathrm{~m}$ (around the poles 9, 10, 13, 14 , and 15). The temperature is higher as well at the area nearly computer and the lecturer for the room height $1.5 \mathrm{~m}$ and $2.0 \mathrm{~m}$. The displacement ventilation fails to spread out the fresh air to those areas. The existing of whiteboard spoils the airflow from the air supply diffuser under it. On the other hand, the mixed ventilation doesn't achieve the area under the lecturer table that's why the temperature is higher.

Fig. 10 shows us the air temperature gradient in the location of poles $1,2,3,4$, and 5 (class front) for air mixed and displacement ventilation system. Almost all of the displacements, the temperature are cooler than that of the mixed ventilation system or more or less the same otherwise little bit more.

For pole 2 under the room height $2.0 \mathrm{~m}$, the temperature of displacement is higher than the mixed ventilation system. Also for pole 3 under the room height $0.5 \mathrm{~m}$, the highest temperature of the displacement ventilation reaches $21.8{ }^{\circ} \mathrm{C}$. That phenomenon occurs due to the existing of the whiteboard and lecturer which are blocking the air supply diffuser airflow.

The coldest temperature is transpired next to the pole 5 area displacement ventilation since there is no obstacle to block the airflow pattern. At the poles 1 and 5 displacement ventilation, the temperature profiles show the unique pattern of the ventilation by means of displacement where the temperature rise while the room height location increase.

The middle position lecturer air temperature condition can be seen at Fig. 11. The temperature gradients are almost uniform for various room heights around 19$20^{\circ} \mathrm{C}$. The omissions are at the poles 8 equally for mixed and displacement ventilation and the pole 6 mixed ventilation. Why the temperature are increase at pole 8 because at those position exist exactly the light as the one of heat sources. Under the room height $0.5 \mathrm{~m}$ pole 6 areas, the temperature gets higher. It happen since the air supply flow mixed ventilation broken by the white board.

The displacement ventilation is superior at the lecturer backside compare to the mixed ventilation in the view of temperature gradient (Fig. 12).

The mixed ventilation fails to flush out the area poles 12 and 14 especially under the room height $0.8 \mathrm{~m}$. Furthermore at the pole 12, the room temperature almost achieves $24^{\circ} \mathrm{C}$. The air velocity is slow down at those areas as we can see at Fig. 7.

\section{CONCLUSION}

The airflow pattern will determine the room thermal conditions which are represented by measurement of velocity and temperature gradient. Room airflow pattern is established by the position of air supply diffuser as well as interior mass inside the room such as in the lecture room.

From the competence of room temperature redu-cing point of view, the displacement ventilation is great means its capability to bring heat through the exhaust diffuser is higher. Even though at the certain area the existing of interior mass will block the airflow furthermore will generate death air area where the room temperature become high.

The others factor which are determine the thermal condition are the number of heat sources in addition to the shape and the room dimension. Therefore the public facilities like the lecture room for instance are required to be careful in the design phase.

Air supply diffuser design and location besides determine the quality of ventilation; it is very often that the aesthetic aspect of the interior room becomes particular consideration by the room designer.

\section{ACKNOWLEDGMENT}

This work has been supported by ITS Strategic Research of LPPM ITS. Contract number: 10474/I2.7/PM/2009.

\section{REFERENCES}

[1] R.B. Holmberg, K. Folkesson, L.G. Stenberg, G. Jansson., 1987, "Experimental analysis of office climate using various air distribution methods". Proceedings of ROOMVENT.

[2] A.R. King, M. Kronfalt, R.F. Clements, 1993, "Stratified air conditioning of large spaces with high heat loads", Australian Refrigeration, Air conditioning and Heating, Vol. 47, No. 2, pp. 24-29.

[3] H. Skistad, 1994, "Displacement ventilation", Research Studies Press Ltd, England.

[4] S. Hu, Q Chen, L.R. Glicksman,.1999, "Comparison of energy consumption between displacement ventilation systems for different U.S. buildings and climates", ASHRAE Transactions, Vol. 105, No. 2, pp. 453-464 
[5] P.V. Nielsen, 1994, "Stratified flow in a room with displacement ventilation and wall-mounted air terminal devices", ASHRAE Transactions, pp. 1163-1169.

[6] P.V. Nielsen, 1996, "Temperature distribution in a displacement ventilation room", Proceedings of ROOMVENT, Vol. 3, pp. 323330.

[7] X. Yuan, Q.Chen, L.R. Glicksman, 1999, "Models for prediction of temperature differences and ventilation effectiveness with displacement ventilation", ASHRAE Transactions, Vol. 105,No. 1, pp. 353-367.
[8] M. Xu, T. Yamanaka, H. Kotani, 1999, "Vertical temperature gradient and ventilation efficiency in rooms with displacement ventilation - influence of supply air temperature and heat load", Technology Reports of Osaka University, Vol. 49, No. 2348, pp. 179-188.

[9] X. Yuan, Q. Chen, L.R. Glicksman, 1998, "Critical review of displacement ventilation", ASHRAE Transactions, Atlanta, GA, USA.

[10]X. Yuan, Q. Chen, L.R. Glicksman, 1999, "Performance evaluation and design guidelines for displacement ventilation", ASHRAE Transactions, Vol. 105, No. 1, pp. 340-352.

TABLE 1.

The DifFerence of Air Temperature BetweEn Experiment AND CFD Simulation for Air MiXed Centre (MC), MiXed Side (MS), DisPlaCEMENT CENTRE (DC) AND DisPLACEMENT SidE (DS) VENTILATION SYSTEM AS THE VALIDATION [13]

\begin{tabular}{|c|c|c|c|c|c|c|}
\hline \multirow{2}{*}{ 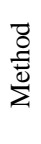 } & \multirow{2}{*}{ No } & \multirow{2}{*}{$\begin{array}{l}\text { Height } \\
\text { Room } \\
\text { (m) }\end{array}$} & \multicolumn{4}{|c|}{ Air Temperature $\left({ }^{\circ} \mathrm{C}\right)$} \\
\hline & & & $\mathrm{mc}$ & $\mathrm{ms}$ & $\mathrm{dc}$ & ds \\
\hline \multirow{5}{*}{ 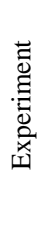 } & 1 & 2.5 & 24.85 & 26.25 & 25.61 & 24.69 \\
\hline & 2 & 2.0 & 23.73 & 25.78 & 24.48 & 24.47 \\
\hline & 3 & 1.5 & 24.30 & 25.50 & 24.63 & 23.89 \\
\hline & 4 & 1.0 & 23.52 & 23.24 & 22.65 & 23.36 \\
\hline & 5 & 0.5 & 22.46 & 23.41 & 21.65 & 22.32 \\
\hline \multirow{6}{*}{ 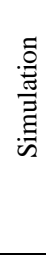 } & 1 & 2.5 & 20.72 & 23.15 & 21.35 & 24.55 \\
\hline & 2 & 2.0 & 20.73 & 23.16 & 21.34 & 24.55 \\
\hline & 3 & 1.5 & 20.76 & 23.16 & 21.32 & 24.54 \\
\hline & 4 & 1.0 & 20.77 & 23.17 & 21.30 & 24.53 \\
\hline & 5 & 0.5 & 20.78 & 23.18 & 21.27 & 24.52 \\
\hline & & $\Delta(\%)$ & 14.57 & 7.22 & 11.66 & 3.23 \\
\hline & & verage $(\%)$ & \multicolumn{4}{|c|}{7.34} \\
\hline
\end{tabular}

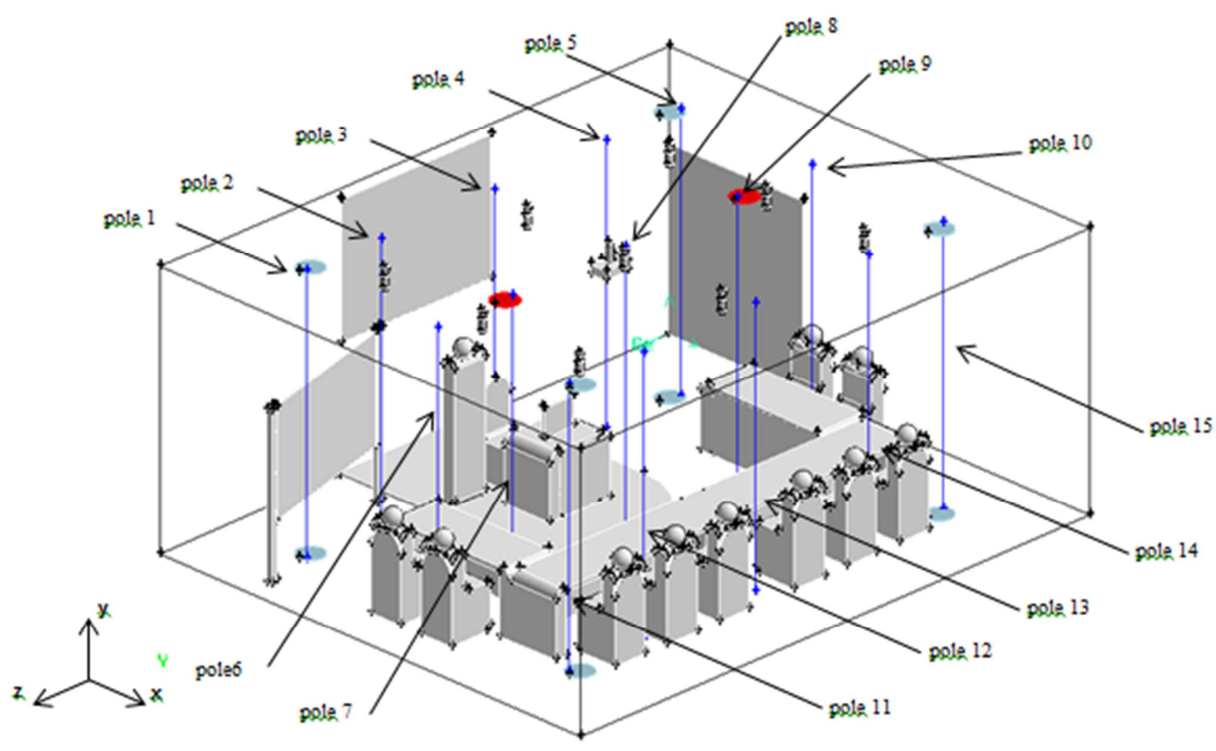

Fig. 2. The lecture room poles position for air velocity and temperature measurement 


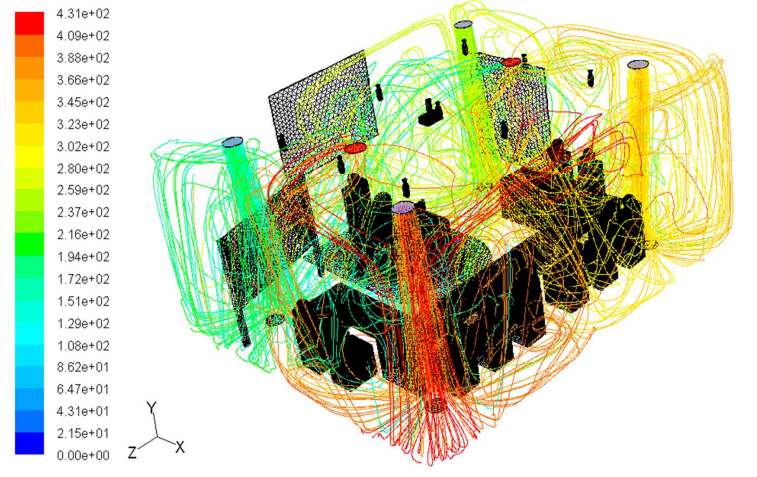

Path Lines Colored by Particle ID FLUENT 6.2 (3d, segregated, lam)

Fig. 3. Path Lines of air mixed ventilation system in the lecture room

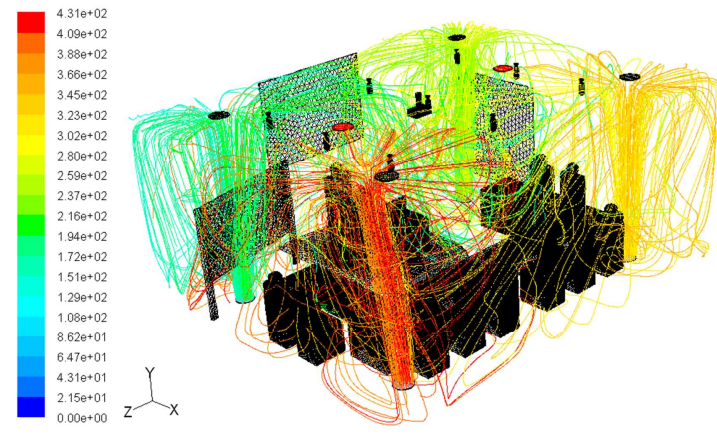

Path Lines Colored by Particle ID Nov 13,2009
FLUENT 6.2 (3d, segregated, lam)

Fig. 4. Path Lines of air displacement ventilation system in the lecture room

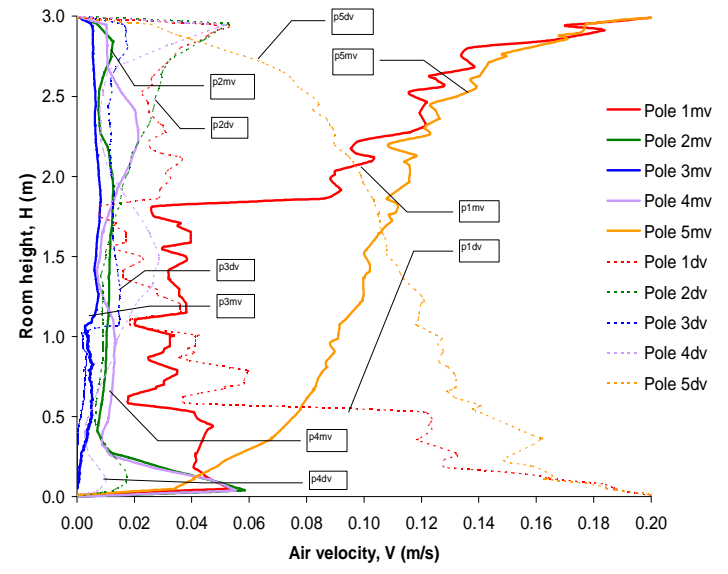

Fig. 5. Air velocity gradient in the location of poles $1,2,3,4$, and 5 for air mixed and displacement ventilation system

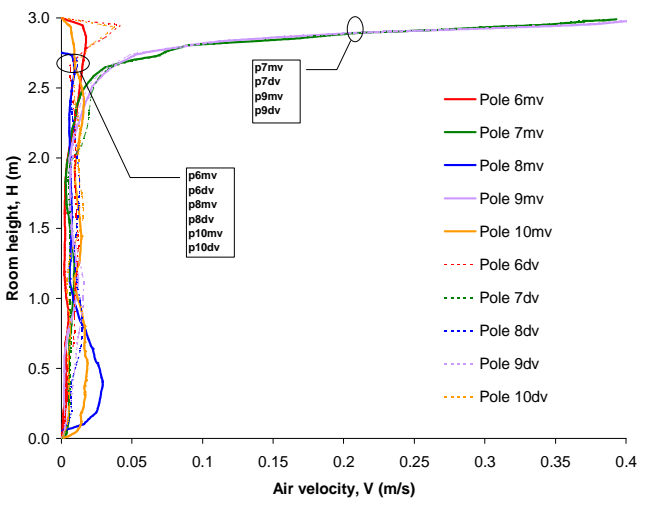

Fig. 6. Air velocity gradient in the location of poles $6,7,8,9$ and 10 for air mixed and displacement ventilation system

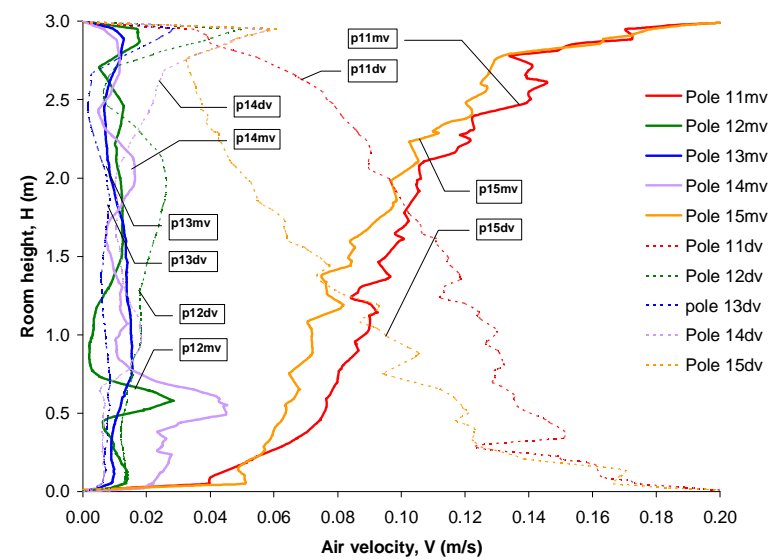

Fig. 7. Air velocity gradient in the location of poles $11,12,13,14$ and 15 for air mixed and displacement ventilation system 

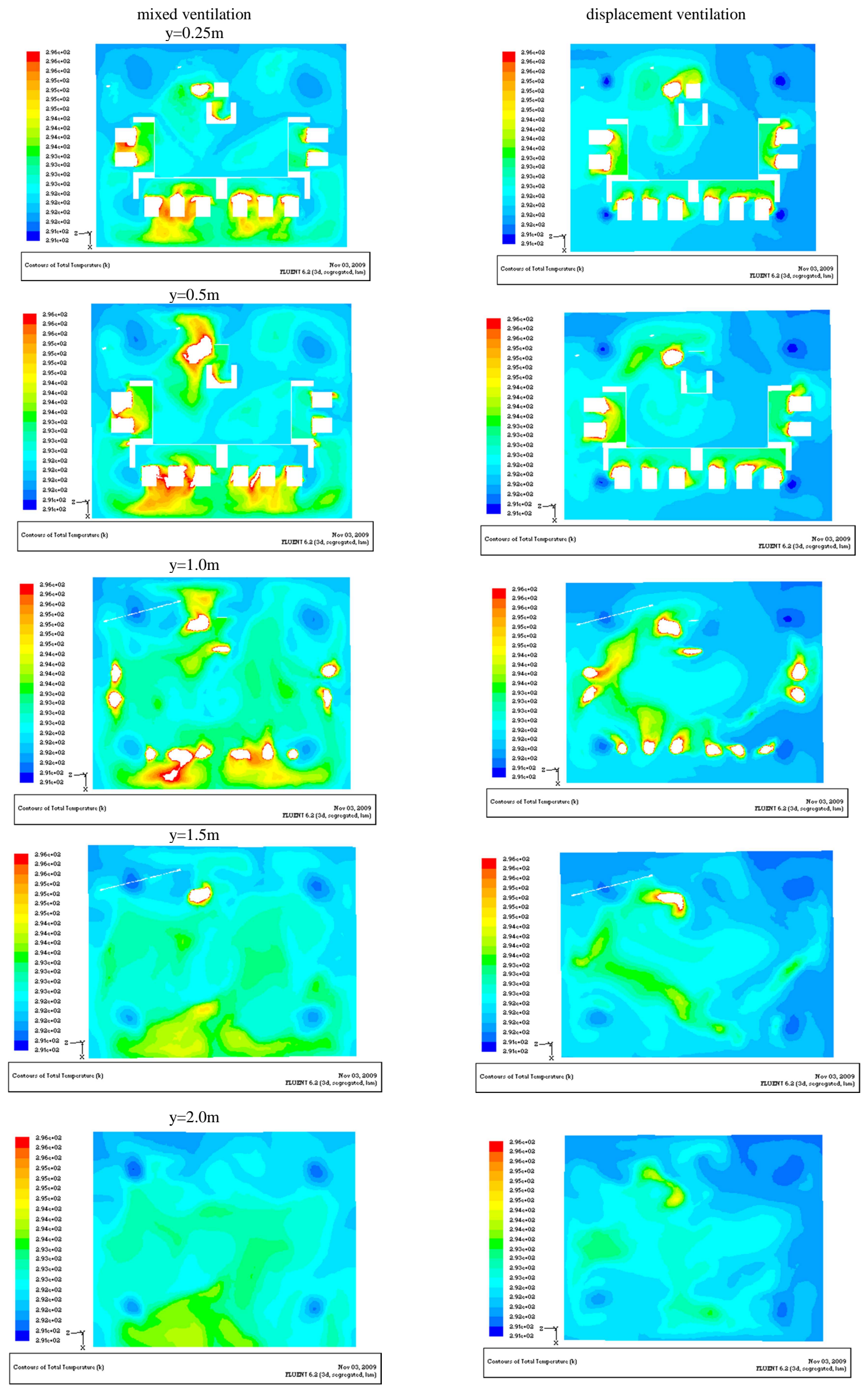

Fig. 8. The temperature contour $\left(18-23^{\circ} \mathrm{C}\right)$ of lecture room used for the ventilation system and height difference (lower zones $0.25 \mathrm{~m}, 0.5 \mathrm{~m}$, and occupational zones: $1.0 \mathrm{~m}, 1.5 \mathrm{~m}$, and $2.0 \mathrm{~m}$ ) 

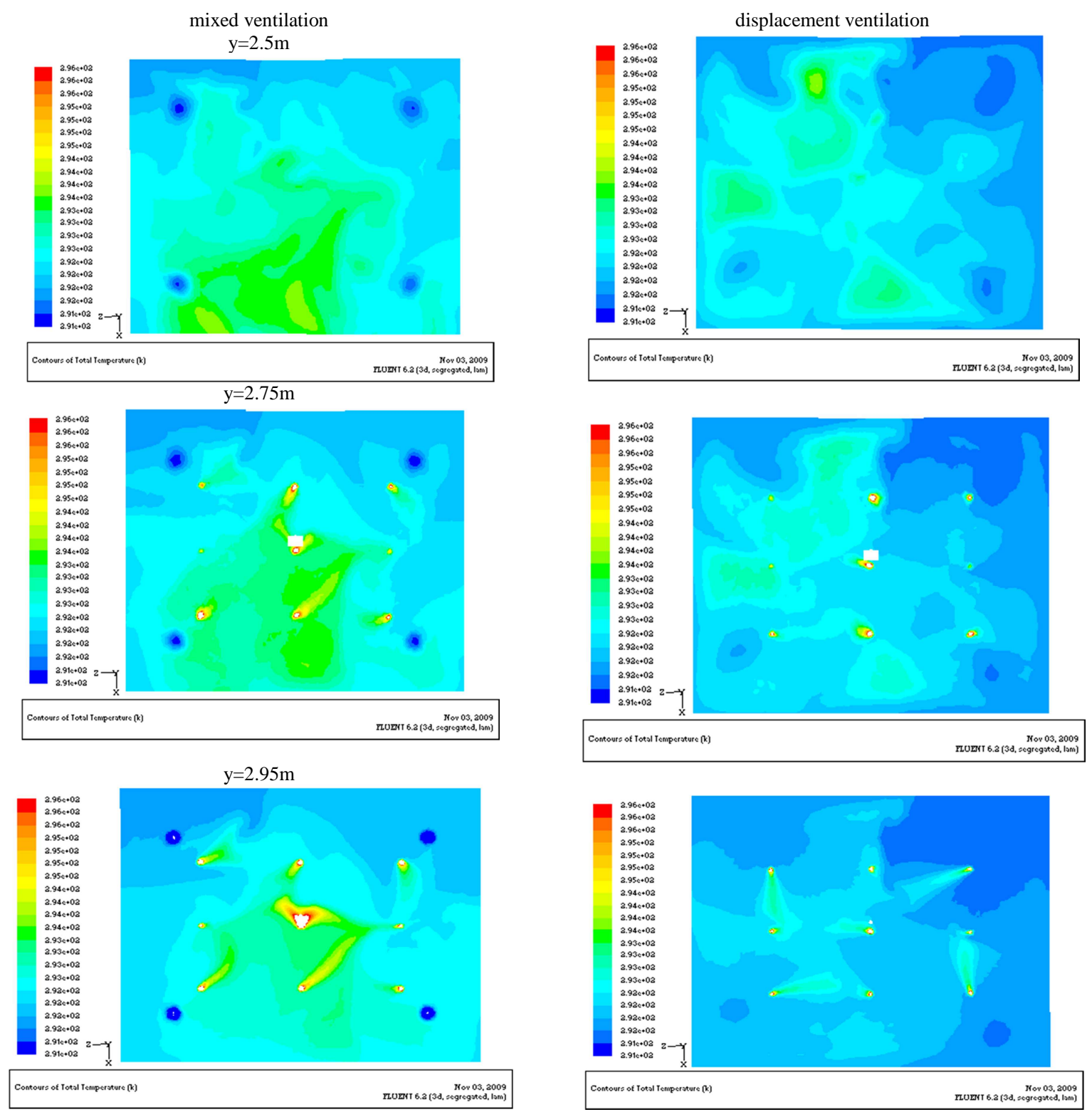

Fig. 9. The temperature contour $\left(18-23^{\circ} \mathrm{C}\right)$ of lecture room used for the ventilation system and height difference (upper zones $2.5 \mathrm{~m}, 2.75 \mathrm{~m}$, and $2.95 \mathrm{~m}$ )

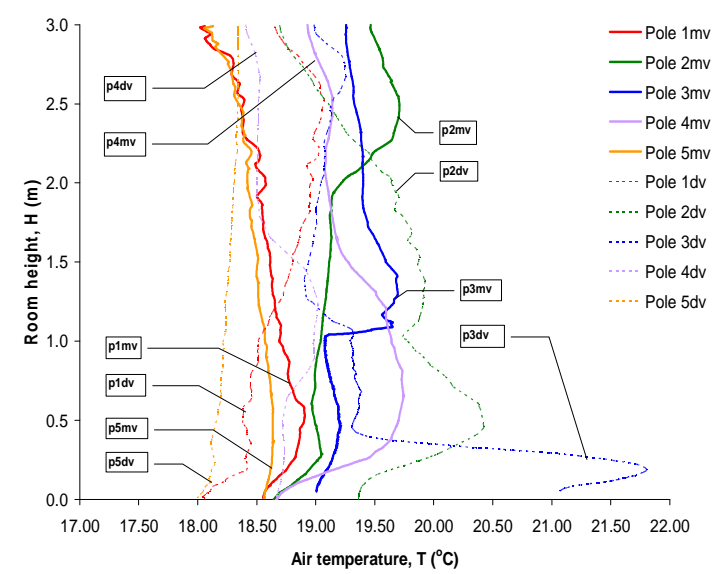

Fig. 10. Air temperature gradient in the location of poles 1, 2, 3, 4, and 5 for air mixed and displacement ventilation system

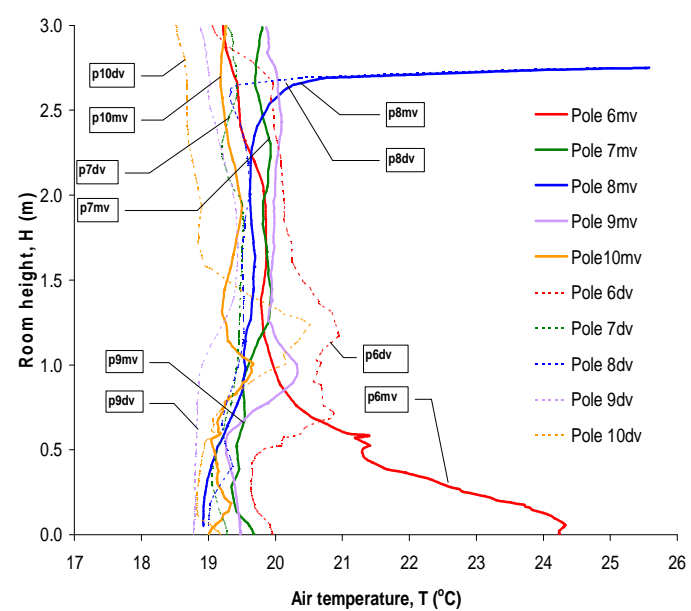

Fig. 11. Air temperature gradient in the location of poles $6,7,8,9$, and 10 for air mixed and displacement ventilation system 


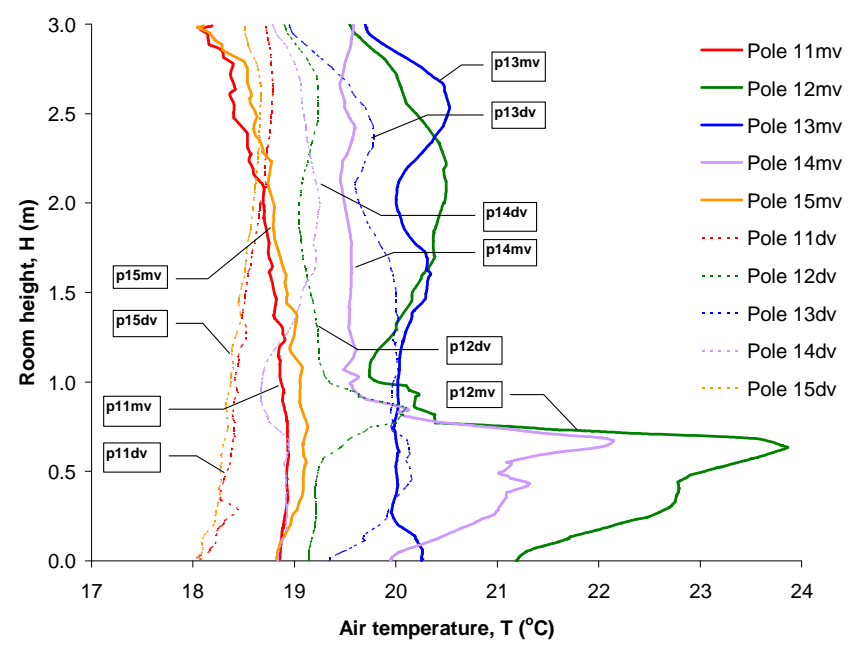

Fig. 12. Air temperature gradient in the location of poles 11, 12, 13, 14, and 15 for air mixed and displacement ventilation system 